RESEARCH ARTICLE

\title{
Variability of Mineral Composition of Rice Landraces Collected from Maharashtra, India
}

V.K. Kauthale, S.M. Patil, A.D. Nalawade

10.18805/ag.DR-1464

\begin{abstract}
Micronutrient malnutrition is one of the burning issues in the rice-based diet area throughout the world. The present study aimed at evaluation of the mineral composition of 77 rice landraces collected from various agro-climatic zones of Maharashtra. The hand-mill processed rice grains were analyzed for eight ( $\mathrm{Na}, \mathrm{Mg}, \mathrm{K}, \mathrm{Ca}, \mathrm{Mn}, \mathrm{Fe}, \mathrm{Co}, \mathrm{Cu}$, and $\mathrm{Zn}$ ) mineral content. Among the mineral contents, the iron content ranged from 2.05 to $12.2 \mathrm{mg} / 100 \mathrm{~g}$, calcium content from 39.2 to $238.47 \mathrm{mg} / 100 \mathrm{~g}$, manganese content from 1.53 to 7.54 $\mathrm{mg} / 100 \mathrm{~g}$, copper content from 0.54 to $3.03 \mathrm{mg} / 100 \mathrm{~g}$ and zinc content ranged from 2.65 to $11.62 \mathrm{mg} / 100 \mathrm{~g}$. The other minerals, like magnesium content in studied landraces, ranged from 81.72 to $278.56 \mathrm{mg} / 100 \mathrm{~g}$, sodium content from 4.73 to $274.34 \mathrm{mg} / 100 \mathrm{~g}$, and potassium content from 148.05 to $670.74 \mathrm{mg} / 100 \mathrm{~g}$. Most of the studied landraces had wide range of variation, rich in minerals and could be a valuable source for bio-fortification of minerals through the breeding method.

Keyword: Landraces, Malnutrition, Mineral content, Rice.

Asian Journal Of Dairy and Food Research (2019)
\end{abstract}

\section{INTRODUCTION}

$\mathrm{R}^{\mathrm{i}}$ (Oryza sativa L.) is the most important cereal in the world, cultivated in a large area. It is a staple food for nearly half of the world's seven billion people (IRRI, 2013). Rice is low in fat and high in starchy carbohydrates, packed full of vitamins and minerals, and provides an excellent source of vitamin E, B vitamins (thiamine, niacin) and Potassium (Renuka et al., 2016). Unfortunately, rice is lacking many essential minerals as iron, zinc and vitamin A. Thus, a ricebased diet is the primary cause of micronutrient malnutrition throughout much of the developing world. Iron, zinc, and vitamin A deficiencies are common in rice-consuming regions (http://www.goldenrice.org/Content2-How/how6_mn.php). Micronutrient malnutrition resulting from the consumption of diets deficient in minerals, vitamins, and essential amino acids affects more than one-half of the world's population, especially women and children in developing countries (UNSCN, 2004, Datta et al., 2006). These deficiencies result in decreased work productivity, reduced mental capacity, stunting, blindness, increased child mortality, and elevated morbidity and mortality in general (http://www.goldenrice. org/Content2-How/how6_mn.php). One of the interventions against micronutrient malnutrition is the breeding of crops through conventional or genetic engineering to accumulate micronutrients in the edible portion (Stein, 2010). Various workers pointed out that the identification of genetic resources with high levels of targeted micronutrients is a necessary step to enhance micronutrient levels through conventional plant breeding (Ortiz-Monasterio et al., 2007; Bouis, 2000). The collection and characterization and screening for desirable characters become fundamental steps towards the genetic improvement of crops. The crop landraces are being served as a valuable gene pool as they contain locally adapted alleles and represent an irreplaceable bank of highly co-adapted genotypes (Qualset et al., 1997).
BAIF Development Research Foundation, Pune, India

Corresponding Author: V.K. Kauthale, BAIF Development Research Foundation, Pune, India, Email: vitthal.kauthale@baif.org.in

How to cite this article: Kauthale, V.K., Patil, S.M. and Nalawade, A.D. (2019). Variability of Mineral Composition of Rice Landraces Collected from Maharashtra, India. Asian Journal Of Dairy and Food Research, 38(3): 242-246.

Source of support: Nil.

Conflict of interest: None

Submitted:11-07-2019 Accepted:21-09-2019 Published: 22-10-2019

However, with the introduction of an industrial production system, crop diversity is the major victim. Therefore, conservation of this valuable gene pool is need of the hour. The objective of present work was to determine the mineral content of rice landraces collected from tribal areas of Maharashtra, India, which will reveal nutritive properties of these unexplored rice landraces and their possible use in breeding programs. Additionally, this study will contribute to the enrichment of food nutrition database.

\section{Materials and methods}

The 77 landraces of rice have been collected from native farmers in Jawhar (Palghar), Akole (Ahmednagar), Junner (Pune), and Etapalli (Gadchiroli) blocks in Maharashtra. The field experiments were conducted during Kharif 2017 at village level in-situ conservation centers of BAIF Development Research Foundation, and seed samples were collected at crop harvest. The hand-mill processed seed samples collected from these in-situ centers were used for analysis. Grain samples were analyzed at the National Agri-Food Biotechnology Institute (NABI), Mohali, Chandigarh. Samples of $0.1 \mathrm{~g}$ were digested with $10 \mathrm{~mL}$ of ICP-MS grade nitric 
acid and diluted to $50 \mathrm{ml}$ with $\mathrm{MQ}$ water. After digestion, the solution was examined for eight elements $(\mathrm{Na}, \mathrm{Mg}, \mathrm{K}$, $\mathrm{Ca}, \mathrm{Mn}, \mathrm{Fe}, \mathrm{Co}, \mathrm{Cu}$, and $\mathrm{Zn}$ ) content using Agilent 7700 series Inductively Coupled Plasma Mass Spectrometry (ICP-MS).

\section{Results AND discussions}

Results of the present study on eight mineral contents in 77 rice landraces showed that many rice landraces are with a wide range of minerals; the result of the analysis is given in Annexure 1. Figure 1 shows the landraces with higher levels of Fe (5 to $12.51 \mathrm{mg} / 100 \mathrm{~g}$ ), $\mathrm{Na}$ (50 to $274.34 \mathrm{mg} / 100 \mathrm{~g}$ ), Mg (140 to $278 \mathrm{mg} / 100 \mathrm{~g}$ ), K (350 to $670 \mathrm{mg} / 100 \mathrm{~g}$ ), Ca (85 to 238.47 $\mathrm{mg} / 100 \mathrm{~g}), \mathrm{Mn}$ (4 to $7.53 \mathrm{mg} / 100 \mathrm{~g}$ ), $\mathrm{Cu}(1 \mathrm{to} 3 \mathrm{mg} / 100 \mathrm{~g}$ ) and Zn (5 to $11.62 \mathrm{mg} / 100 \mathrm{~g}$ ) among studied 77 landraces.

The calcium content in studied landraces ranged from 39.2 to $238.47 \mathrm{mg} / 100 \mathrm{~g}$, and 31 landraces showed more than $85-\mathrm{mg} / 100 \mathrm{~g}$ calcium. Among those landraces, Khadkya (238.47 mg/100 g), Mahadi (197.05 mg/100 g), Hali kolpi $(194.98 \mathrm{mg} / 100 \mathrm{~g})$, Dangi-red $(180.82 \mathrm{mg} / 100 \mathrm{~g})$ and Varangal ( $179.92 \mathrm{mg} / 100 \mathrm{~g})$ were found with the highest calcium content. Thomas et al. (2015) reported 12.42 to 21.38 $\mathrm{mg} / 100 \mathrm{~g}$ calcium in different rice varieties. The iron content in studied landraces ranged from $2.05-12.2 \mathrm{mg} / 100 \mathrm{~g}$. About 55 landraces found with more than $5 \mathrm{mg} / 100 \mathrm{~g}$ of iron content. Kalbhat (12.21 mg/100 g), Khadkya (11.51 mg/100 g), Jay-shriram (11.37 mg/100 g), Tornya $(9.64 \mathrm{mg} / 100 \mathrm{~g})$ and Masala $(8.98 \mathrm{mg} / 100 \mathrm{~g})$ were found with highest iron content. Iron deficiency is the most common nutritional disorder in the world, affecting over 4 billion people, with more than 2 billion people, mainly in developing countries, actually being anemic [http://www.who.int/nut/ida.htm]. Improved rice varieties developed for higher iron, contains 19.8 to 37.5 ppm (1.98 to $3.75 \mathrm{mg} / 100 \mathrm{~g}$ ) iron (Ravindra Babu 2013). Among the transgenic lines developed by Krishnan et al. (2009), Fe content was recorded $21 \mathrm{mg} / \mathrm{kg}$ in the unpolished IR68144 and $15 \mathrm{mg} / \mathrm{kg}$ in BR29 and polished rice grains of IR68144 and BR29 it was 15 and $8.9 \mathrm{mg} / \mathrm{kg}$, respectively. The results clearly showed that most of the studied landraces are superior in the matter of iron content.

The magnesium content in studied landraces ranged from 81.72 to $278.56 \mathrm{mg} / 100 \mathrm{~g}$. The landraces Tulshya $(278.56$ $\mathrm{mg} / 100 \mathrm{~g})$, Lalkabara (269.87 mg/100g), Hali Kolamba (268.94 mg/100g), Ambemohar (253.52 mg/100g) and Gandha (239.12 $\mathrm{mg} / 100 \mathrm{~g}$ ) were found highest magnesium content. Out of studied 77 landraces, 42 landraces contained magnesium more than $140 \mathrm{mg} / 100 \mathrm{~g}$. The sodium content in studied landraces ranged from 4.73 to $274.34 \mathrm{mg} / 100 \mathrm{~g}$. Thirty-two landraces found more than $50 \mathrm{mg} / 100 \mathrm{~g}$ sodium content. Khadkya (274.34 mg/100g), Dhavalbhat (193.18mg/100g), Kamod $(173.48 \mathrm{mg} / 100 \mathrm{~g})$, Kirtibhat $(172.10 \mathrm{mg} / 100 \mathrm{~g})$ and Varangal $(170.46 \mathrm{mg} / 100 \mathrm{~g})$ landraces found with highest sodium content. The potassium content in studied landraces ranged from 148.05 to $670.74 \mathrm{mg} / 100 \mathrm{~g}$. Tulshya $(670.74$ $\mathrm{mg} / 100 \mathrm{~g})$, Ambemohar (624.45 mg/100g), Namoku (608.12 $\mathrm{mg} / 100 \mathrm{~g})$, DRK-2 (596.42 mg/100g) and Lalkabara (577.55 $\mathrm{mg} / 100 \mathrm{~g}$ ) landraces found with highest potassium content. The 38 landraces were contained more than $350 \mathrm{mg} / 100 \mathrm{~g}$ potassium. The manganese content in studied landraces ranged from 1.53 to $7.54 \mathrm{mg} / 100 \mathrm{~g}$. Noon $(7.54 \mathrm{mg} / 100 \mathrm{~g})$, Pitris $(7.52 \mathrm{mg} / 100 \mathrm{~g})$, Tulshya $(7.43 \mathrm{mg} / 100 \mathrm{~g})$, Kirtibhat (6.65 $\mathrm{mg} / 100 \mathrm{~g})$ and Salbhat $(6.57 \mathrm{mg} / 100 \mathrm{~g})$ landraces found with highest manganese content. The 39 landraces contained more than $4 \mathrm{mg} / 100 \mathrm{~g}$ manganese.

The copper content in studied landraces ranged from 0.54 to $3.03 \mathrm{mg} / 100 \mathrm{~g}$. The 45 landraces contained more than $1 \mathrm{mg} / 100 \mathrm{~g}$ copper. Sonphal (3.03 mg/100g), Hali kolpi (2.25 $\mathrm{mg} / 100 \mathrm{~g})$, Raibhog (2.06 mg/100g), Kalbhat $(2.05 \mathrm{mg} / 100 \mathrm{~g})$ and Garikolapi $(1.95 \mathrm{mg} / 100 \mathrm{~g})$ landraces found with highest copper content. Renuka et al. (2016) reported vast variation in 39 rice varieties in respect to zinc content $(25 \mu \mathrm{g} / \mathrm{g}$ to $165 \mu \mathrm{g} / \mathrm{g})$.

The zinc content in studied landraces ranged from 2.65 to $11.62 \mathrm{mg} / 100 \mathrm{~g}$. Khadkya (11.62 mg/100g), Noon (10.57 mg/100g), Sonphal $9.57 \mathrm{mg} / 100 \mathrm{~g})$, Kirtibhat (9.32 $\mathrm{mg} / 100 \mathrm{~g})$ and Varangal $(7.68 \mathrm{mg} / 100 \mathrm{~g})$ landraces found with highest zinc content. The 49 landraces contained more than $5 \mathrm{mg} / 100 \mathrm{~g}$ zinc. Deb et al., (2015) reported 2.4 to $44.9 \mathrm{mg} / \mathrm{kg}$ (0.24 to $4.49 \mathrm{mg} / 100 \mathrm{~g})$ zinc content in 130 rice landraces except for Garibsaal, which is known for its medicinal properties in gastro-intestinal ailments, contains extraordinary amount $(155 \mathrm{mg} / \mathrm{kg}$ ) of zinc. In the present study, also few landraces like Khadkya $(11.62 \mathrm{mg} / 100 \mathrm{~g})$ Noon $(10.57$ $\mathrm{mg} / 100 \mathrm{~g}$ ) and Sonphal $(9.57 \mathrm{mg} / 100 \mathrm{~g})$ contain higher zinc. The rice landraces with overall higher mineral contents are depicted in Table 1. Tulashya and Khadkya contain an overall

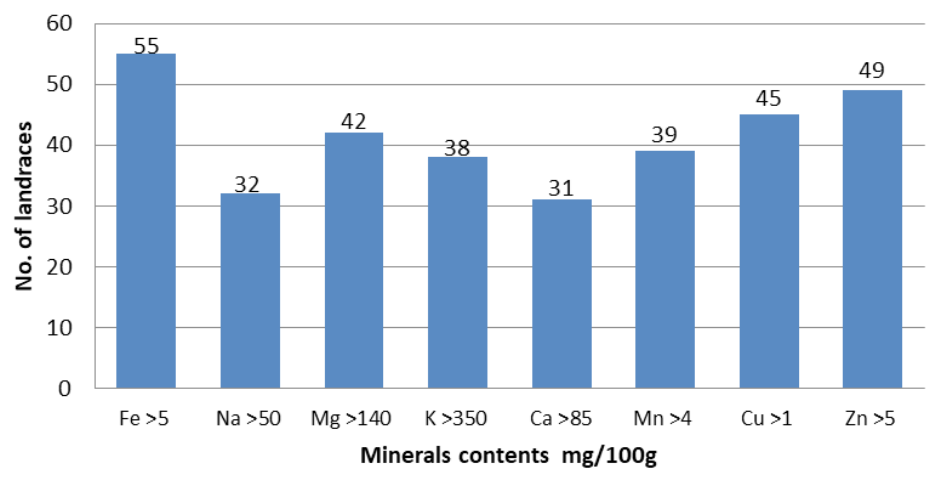

Figure 1: Number of rice landraces with high levels of minerals in grains 
Variability of Mineral Composition of Rice Landraces Collected from Maharashtra, India

Table 1: Selected rice landraces with highest mineral contents in studied samples $(\mathrm{mg} / 100 \mathrm{~g})$

\begin{tabular}{|c|c|c|c|c|c|c|c|c|}
\hline Landraces & Iron & Sodium & Magnesium & Potassium & Calcium & Manganese & Copper & Zinc \\
\hline Ambemohar & 7.24 & 156.81 & 253.52 & 624.45 & 109.55 & 6.14 & 1.61 & 6.50 \\
\hline Hali Kolamba & 5.90 & 136.74 & 268.94 & 560.47 & 102.80 & 5.00 & 1.80 & 7.08 \\
\hline Kirtibhat & 5.16 & 172.10 & 198.52 & 476.46 & 138.24 & 6.65 & 1.58 & 9.32 \\
\hline Sonphal & 7.73 & 21.84 & 237.76 & 531.05 & 79.18 & 3.50 & 3.03 & 9.57 \\
\hline Tulshya & 8.08 & 144.28 & 278.56 & 670.74 & 94.88 & 7.43 & 1.79 & 7.25 \\
\hline Khadkya & 11.51 & 274.34 & 228.51 & 517.83 & 238.47 & 5.30 & 1.87 & 11.62 \\
\hline Kalbhat & 12.21 & 125.21 & 205.80 & 524.31 & 92.94 & 5.16 & 1.70 & 5.45 \\
\hline Varangal & 4.20 & 170.46 & 169.30 & 311.38 & 179.92 & 3.90 & 1.72 & 7.68 \\
\hline Malghudya & 8.52 & 137.67 & 147.51 & 290.64 & 139.41 & 2.54 & 0.93 & 5.23 \\
\hline Kalbhat & 12.21 & 125.21 & 205.80 & 524.31 & 92.94 & 5.16 & 1.70 & 5.45 \\
\hline
\end{tabular}

higher amount of most of the minerals among the studied landraces.

Several traditional rice varieties are considered in folk medicine to have high nutritive and therapeutic value and found rich in minerals (Deb et al., 2015). The indigenous traditional knowledge indicated that collected landraces are being utilized for various purposes like diet for nursing mothers (Malgudya, Rajgudya, Dhavul), fracture recovery (Mahadi), weakness recovery (Dangi-red, Kasbai) etc. However, these community claims need to be scientifically validated.

\section{Conclusions}

The present study reported a wide range of mineral accumulation, including $\mathrm{Cu}, \mathrm{Fe}, \mathrm{Mn}, \mathrm{Zn}$ and $\mathrm{Mg}$ in handmilled seeds of 77 rice landrace. This has indicated that there is a good scope to locate and promote such high mineralrich varieties for cultivation and human consumption. The outcome of the study will also facilitate plant breeders to choose desired parents for a breeding program to articulate the nutrient-rich varieties and address the malnutrition aspect in regards to most of the cereal crops.

\section{Acknowledgment}

The authors are thankful to Rajiv Gandhi Science and Technology Commission, Government of Maharashtra for financial support; Maharashtra Gene Bank Project team for field support, Dr. Avinash Joshi for his valuable suggestions and National Agri-Food Biotechnology Institute (NABI), Mohali, Chandigarh, India for analysis of rice samples.

\section{References}

Bouis, H. E. (2000). Enrichment of food staples through plant breeding: a new strategy for fighting micronutrient malnutrition. Nutrition 16, 701-704.

Datta, K., Rai, M., Parkhi, V., Oliva, N., Tan, J., \& Datta, S. K. (2006). Improved 'golden' indica rice and post-transgeneration enhancement of metabolic target products of carotenoids (b-carotene) in transgenic elite cultivars (IR64 and BR29). Current Science, 91, 935-939.

Deb, D., Sengupta, S. and Pradeep,T. (2015). A profile of heavy metals in rice (Oryzasativa ssp. indica) landraces. Curr Sci., 109 (3): 407-409

http://www.goldenrice.org/Content2-How/how6_mn.php

http://www.who.int/nut/ida.htm

IRRI, 2013. Trends in global rice consumption: Rice Today. International Rice Research Institute, Manila, Philippines.12: 1.

Krishnan, S., Datta, K., Parkhi,V. and Datta,S. K.(2009). Rice caryopsis structure in relation to distribution of micronutrients (iron, zinc, b-carotene) of rice cultivars including transgenic indica rice. Plant Sci, 177: 557-562.

Ortiz-Monasterio, J. I., Palacios-Rojas, N., Meng, E., Pixley,K., Trethowan, R. and R. J. Pena. (2007). Enhancing the mineral and vitamin content of wheat and maize through plant breeding. J Cereal Sci., 46, 293-307.

Qualset, C.O., Damania,A.B., Zanatta,A.C.A. and Brush, S.B. (1997). Locally based crop plant conservation. In: Maxted N., Ford Lloyd B. and Hawkes J.G. (ed.), Plant Genetic Conservation: The in-situ Approach, ISBN 0412637308, Chapman \& Hall, London, pp. 160-175.

Ravindra Babu V. (2013). Importance and advantages of rice biofortification with iron and zinc. Journal of SAT Agricultural Research 11.

Renuka, N., Mathure, S. V., Zanan, R. L., Thengane, R. J. and Nadaf, A. B. (2016). Determination of some minerals and b-carotene contents in aromatic indica rice (Oryza sativa L.) germplasm. Food Chemistry 191 2-6

Stein, A. J. (2010). Global impacts of human mineral malnutrition. Plant Soil,335, 133-154.

Thomas, R., Bhat, R. and Kuang,Y.T. (2015). Composition of amino Acids, fatty acids, minerals and dietary fiber in some of the local and import rice varieties of Malaysia. INT FOOD RES J. 22(3): 1148-1155

UNSCN, (2004), $5^{\text {th }}$ Report on the world nutrition situation, Nutrition for improvement development outcomes United Nation as system Standing Committee on Nutrition, Geneva, Switzerland. 
Variability of Mineral Composition of Rice Landraces Collected from Maharashtra, India

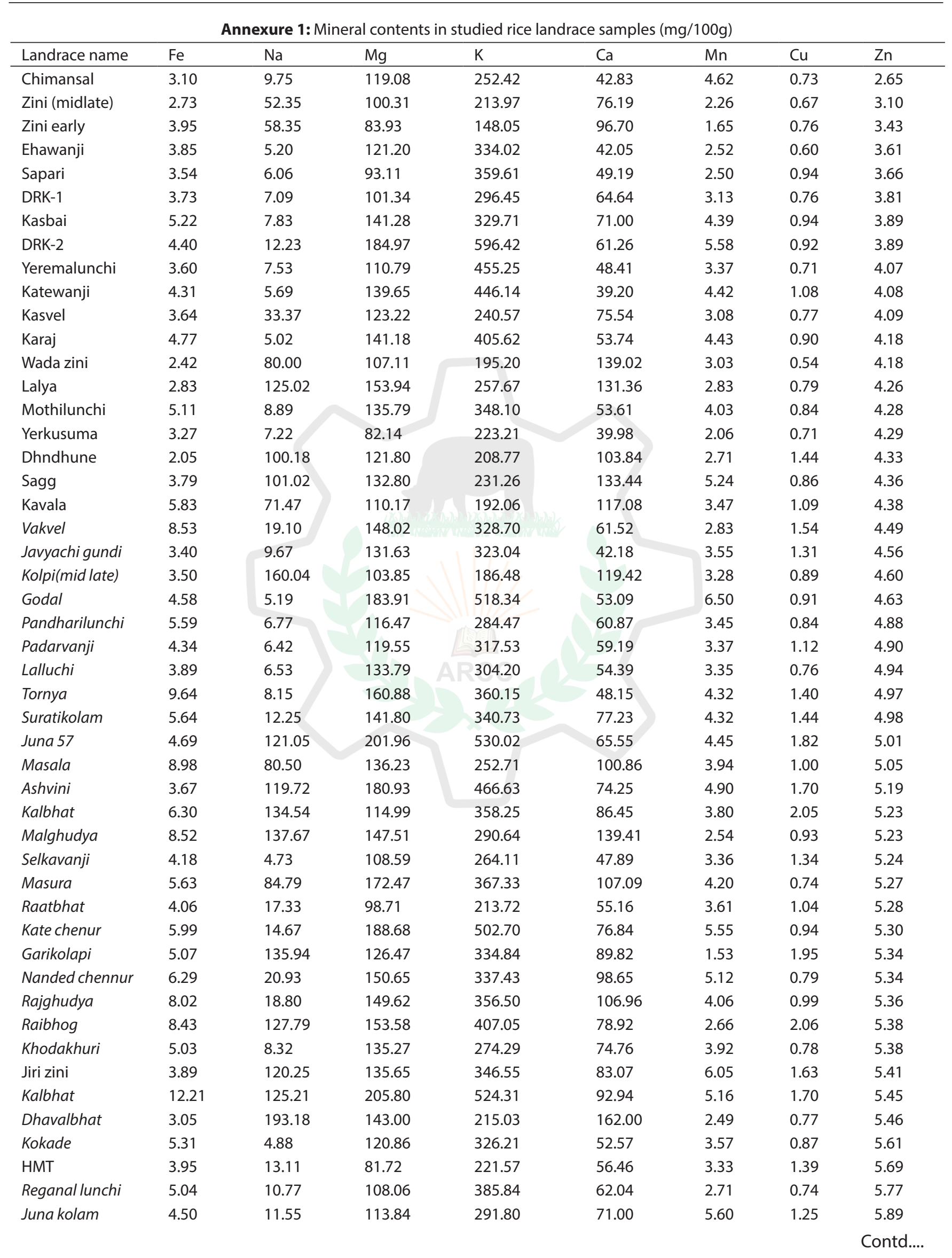




\begin{tabular}{|c|c|c|c|c|c|c|c|c|}
\hline Jaymahadev & 4.27 & 10.81 & 151.16 & 452.47 & 60.75 & 5.62 & 0.98 & 5.90 \\
\hline Jirvel & 7.90 & 135.33 & 165.38 & 434.71 & 111.50 & 2.50 & 1.69 & 5.97 \\
\hline Sodui & 4.15 & 15.58 & 182.79 & 411.74 & 66.07 & 4.00 & 0.96 & 6.14 \\
\hline Kamal bhat & 5.45 & 140.60 & 156.97 & 396.10 & 83.20 & 3.96 & 1.53 & 6.16 \\
\hline Kamod & 4.35 & 173.48 & 181.68 & 411.51 & 91.25 & 4.10 & 1.39 & 6.19 \\
\hline Sadhana bhat & 3.52 & 124.49 & 134.48 & 325.73 & 62.69 & 3.58 & 1.52 & 6.22 \\
\hline Mahadi (midlate) & 6.00 & 44.66 & 139.44 & 262.61 & 197.05 & 4.20 & 1.27 & 6.27 \\
\hline Dula-2 & 4.74 & 24.85 & 150.93 & 362.58 & 56.33 & 5.26 & 1.48 & 6.28 \\
\hline Nanded-92 & 4.49 & 15.90 & 128.21 & 382.08 & 91.38 & 4.24 & 1.16 & 6.30 \\
\hline Vijay Nanded & 4.37 & 16.79 & 121.47 & 324.14 & 78.14 & 3.73 & 1.04 & 6.35 \\
\hline Goti & 7.20 & 7.34 & 212.83 & 517.56 & 69.96 & 4.97 & 1.27 & 6.42 \\
\hline Ambemohar & 7.24 & 156.81 & 253.52 & 624.45 & 109.55 & 6.14 & 1.61 & 6.50 \\
\hline Gandha & 4.57 & 7.00 & 239.12 & 564.77 & 61.78 & 5.87 & 1.36 & 6.57 \\
\hline Dangi (red) & 3.00 & 136.99 & 143.90 & 293.41 & 180.82 & 4.46 & 1.33 & 6.59 \\
\hline Lalkabara & 6.60 & 5.12 & 269.87 & 577.55 & 50.88 & 6.06 & 1.18 & 6.63 \\
\hline Salbhat & 8.91 & 10.03 & 185.27 & 409.15 & 54.12 & 6.57 & 1.18 & 6.76 \\
\hline Namoku & 6.14 & 5.99 & 210.69 & 608.12 & 71.13 & 5.43 & 1.23 & 6.78 \\
\hline Pacheki & 6.52 & 125.20 & 185.85 & 316.66 & 146.94 & 3.84 & 0.97 & 7.00 \\
\hline Pitris & 5.12 & 6.95 & 221.42 & 496.03 & 80.61 & 7.52 & 1.20 & 7.02 \\
\hline Hali kolamba & 5.90 & 136.74 & 268.94 & 560.47 & 102.80 & 5.00 & 1.80 & 7.08 \\
\hline Tulshya & 8.08 & 144.28 & 278.56 & 670.74 & 94.88 & 7.43 & 1.79 & 7.25 \\
\hline Jayshriram & 11.37 & 40.18 & 189.98 & 481.45 & 136.17 & 5.67 & 1.12 & 7.39 \\
\hline Hari kolpi & 5.26 & 117.41 & 187.46 & 385.69 & 194.98 & 2.75 & 2.25 & 7.58 \\
\hline Varangal & 4.20 & 170.46 & 169.30 & 311.38 & 179.92 & 3.90 & 1.72 & 7.68 \\
\hline Kirtibhat & 5.16 & 172.10 & 198.52 & 476.46 & 138.24 & 6.65 & 1.58 & 9.32 \\
\hline Sonphal & 7.73 & 21.84 & 237.76 & 531.05 & 79.18 & 3.50 & 3.03 & 9.57 \\
\hline Noon & 7.73 & 7.03 & 204.11 & 487.97 & 88.52 & 7.54 & 1.18 & 10.57 \\
\hline Khadkya & 11.51 & 274.34 & 228.51 & 517.83 & 238.47 & 5.30 & 1.87 & 11.62 \\
\hline Range & $\begin{array}{l}2.05 \\
-12.21\end{array}$ & $\begin{array}{l}4.73- \\
274.00\end{array}$ & $\begin{array}{l}81.71- \\
278.00\end{array}$ & $148.04-670.00$ & $\begin{array}{l}39.19- \\
238.47\end{array}$ & $\begin{array}{l}1.53- \\
7.53\end{array}$ & $\begin{array}{l}0.53- \\
3.03\end{array}$ & $\begin{array}{l}2.65- \\
11.62\end{array}$ \\
\hline
\end{tabular}

